\title{
Challenging the traditional curriculum by traditional knowledges: from ethnomathematical fieldwork to classroom practices
}

\author{
José Ricardo e Souza Mafra
}

\begin{abstract}
This paper provides a discussion related to the development of educational practices, having as basic assumptions the planning, organization and implementation of an ethnographic field research, from the production of decorated and incised bowls, by women artisans, Aritapera region, state from Pará, northern Brazil. We present the initial development of the proposal, carried out in the Aritapera region, based on joint planning with teachers from the region, based on the design of a set of local activities for later implementation in the classroom. With this investigation, it is expected to contribute to the field of research in ethnomathematics, by bringing empirical reflections aiming at the implementation of local curricular practices, based on good educational practices.
\end{abstract}

Keywords: Ethnography. Ethnomathematics education. Local mathematical practices. Mathematics curriculum.

\section{Desafiando el currículo tradicional por los conocimientos tradicionales: del trabajo de campo etnomatemático a las prácticas en el aula}

Resumen: Este documento proporciona una discusión relacionada con el desarrollo de prácticas educativas, teniendo como suposiciones básicas la planificación, organización e implementación de una investigación de campo etnográfica, a partir de la producción de cuencos decorados e incisos, por mujeres artesanas, región de Aritapera, estado de Pará, norte de Brasil. Presentamos el desarrollo inicial de la propuesta, realizada en la región de Aritapera, basada en la planificación conjunta con los docentes de la región, basada en el diseño de un conjunto de actividades locales para su posterior implementación en el aula. Con esta investigación, se espera que contribuya al campo de la investigación en Etnomatemática, al

José Ricardo e Souza Mafra 'Doctor in Education (concentration area: Mathematical Education) by Federal University of Rio Grande do Norte (UFRN). Professor of the Postgraduate Program in Education by the Federal University of West of Pará (UFOPA), Pará, Brazil.

(iD) http://orcid.org/0000-0002-3629-8959

$\triangle$ jose.mafra@ufopa.edu.br

Received in 08/09/2019 Accepted in 07/12/2019 Published in 04/03/2020 traer reflexiones empíricas destinadas a la implementación de prácticas curriculares locales, basadas en buenas prácticas educativas.

Palavras clave: Etnografía. Educación en etnomatemáticas. Prácticas matemáticas locales. Currículo matemático.

\section{Desafiando o currículo tradicional por conhecimentos tradicionais: do trabalho de campo etnomatemático às práticas em sala de aula}

Resumo: Este artigo fornece uma discussão relacionada ao desenvolvimento de práticas educacionais, tendo como pressupostos básicos o planejamento, a organização e implementação de uma pesquisas de campo etnográfica, a partir da produção de cuias decoradas e incisas, por mulheres artesãs, região de Aritapera, estado do Pará, norte do Brasil. Apresentamos o desenvolvimento inicial da proposta, realizada na região de Aritapera, a partir do planejamento conjunto com professores da região, com base no dimensionamento de um conjunto de atividades locais, para implementação posterior, em sala de aula. Com essa investigação, espera-se contribuir para o campo de pesquisa em Etnomatemática, ao trazer reflexões empíricas visando a efetivação de prática curriculares locais, a partir de boas práticas educacionais.

Palavras-chave: Etnografia. Educação etnomatemática. Práticas matemáticas locais. Currículo de Matemática. 


\section{Introduction}

Ethnomathematics has become a field of permanent interest of essentially interdisciplinary research. His epistemological understanding has always presented a permanent intertwining of diverse and sometimes even contradictory theories and areas of knowledge, such as anthropology, sociology, cultural studies, mathematics and pedagogy. This work is part of a permanent effort by a collaborative group of four researchers from different backgrounds, located in different geographic regions. Involved in studies related to the ethnomathematics program, their research, reflected from their historical trajectories, provides indicators and references for thinking and projecting elements of reflections on sociocultural practices and how these practices can be enhanced, as a vector of pedagogical possibility for local implementations of social and cultural practices (VARGAS, 2009).

In this sense, the studies and preliminary results presented here may provide an expansion of possibilities based on two long-term empirical ethnographic investigations of different places and peoples. One of these researches was developed at the North Ambrymese Society (Ambrym Island, Vanuatu, South Pacific); the Paraguayan Chaco and the Trobriand Islands, Papua New Guinea. The other research, writing basis for this work, is being developed in the Aritapera region, rural area of the city of Santarém, state of Pará, northern Brazil, based on the traditional knowledge of artisans from the city of Santarém, organized since 2003, through the Association of Santarém Riverside Artisans (ASARISAN) and whose work deals with the production of handcrafted bowls (MADURO, 2013; FANTINATO \& MAFRA, 2017).

Thus, the focus of discussion in this article projects the outline of: i) how was the initial development of the partnership between the researchers and the teachers involved in the proposal, ii) the theoretical discussions and initial studies carried out, iii) the elaboration and configuration modules of teaching activities, focusing on local knowledge.

In this survey, the study involved a detailed description of the planning activities of the working group: researcher and teachers from the Aritapera community. The organized methodological procedures, in general, involved elements of ethnographic research, with the objective of seeking a dense description of events related to the research (GEERTZ, 2008). The investigation was based on the assumption of immersion in the researcher in the environment in which the object of study is located, (BOGDAN \& BIKLEN, 1994), indicating the researcherobserver as the main instrument in the collection and subsequent analysis of data, thus characterizing a study from the perspective of ethnomathematics. The data collection techniques used were observation with notes in the field diary, interview, photography and filming, with the 
appropriate authorizations.

An analysis perspective, for this proposal, is based on the principle that it is possible to understand the mathematical processes interconnected and/or articulated with a sense and a reason to exist, therefore favoring gradually the capacity for abstraction and the development of the capacity of reasoning. As an example, we can cite-as future guidelines onin this proposal - a systematic study of patterns and metrics used by craftswomen and their similarities, in terms of strategies used in school contexts, for students.

A category of analysis to be discussed would be, for example, the topological notion of dimensioning configurations in spaces and curved surfaces, evidenced in the work of craftswomen and how these categories approach the thought and elaboration of references of construction of these surfaces, in school practices, produced by students.

The methodological referrals were made from: (i) planning and operational organization of experimental activities, based on local culture, (ii) collaboration with local educators, (iii) the epistemological content of the planned activities and (iv) the new knowledge, discussed with the teachers. Thus, discussions about the implementation of these practices are projected, based on effective classroom activities, aiming to improve vital and necessary knowledge for the development of school skills, such as: mathematical abstraction, concentration, self-assessment and comprehension. Of relationships and spatial transformations.

Concluding this section, an initial discussion is projected under different analysis lenses, such as the development of educational investigations, focusing on local knowledge, as well as an expansion of the instrumentation and theoretical knowledge, focused on sociocultural research, in the field of ethnomathematics, from an educational perspective, focusing on some reference points, which we will elaborate in the next section on the theoretical framework.

\section{Theoretical assumptions}

Our theoretical framework projects reference points from the empirical cases developed at the research site. We understand that, as educators and researchers based on anthropological and ethnographic studies, different perspectives and referrals related to the study of local practices, by academy researchers, allow us to provide an understanding of the theoretical framework used and allied to ethnographic research, situate those involved in the research. based on ethnomathematics. In our discussions, critical and long-term ethnographic research situates those involved in studies and research, based on their experiences and integration with the social and 
cultural practices investigated.

Thus, the theoretical questions developed by previous studies resonate with the research investigations, centered in this work, on local practices. This assumption allows us to add, in terms of reflection, possible additional objectives or side effects of the study, regarding the identification and location of a political engagement of field research, projecting the reconfiguration of local practices, in order to provide sustainability to the field. Cultural diversity. These reference points are related to contemporary theoretical debates on ethnomathematics and its expansion of discussion and knowledge production. In the work developed by Pais (2011), it is possible to discuss issues related to the philosophical debate involving the concept of the 'other' and its effects, in view of the abstraction of information related to empirical data and acquired experiences, during ethnographic research in mathematics. Just as Žižek's (1997) critique of the other's conception is central to understanding evolution in the way ethnomathematics is conducted. Thinking about theoretical issues, we project discussions and reflections that are mostly made from a perspective of studies and research on local and cultural practices. In D'Ambrosio (1997) and Greenfield e Lave (1979) we find issues related to the hegemony of anthropological work, which provides an initial indicator to think about new methodologies (e. g, critical ethnographic research or even sociocultural practices in the classroom). Thus, the object of study becomes a stakeholder in research planning, just as we become part of a projection, in terms of collaborative and involved research. As a researcher, in fact, we have to be aware of the different perspectives, if we are talking in terms of generated discussions, based on data from an investigation. What becomes challenging is the perspective of how the interaction between researchers and local residents occurs, where these local practices and knowledge rest, and how they both see and "strangely" at first.

These relationships allow us to project inferences about how the development of a local curriculum can take place based on their own practices. In addition, the production of local knowledge provides indicators of how dynamic exchanges and social relations take place, based on the commercialization of their local practices. From this perspective, we can observe the goal of the local population to engage in the global world and how the "western" researcher becomes the exotic and different "other". Knowing that we are always the "other" in ethnomathematical research, we hope to contribute to the answers to our research questions, even though we know that it is not our intention to carry out sophisticated theoretical development, but rather to think about good educational practices, with based on our field of research in ethnomathematics. 


\section{Research context and project participants}

The educational experience here presented is linked to a post-doctoral research carried out by the first author and supervised by the second author, during the year of 2015, Mafra e Fantinato (2016). This research had as main objective the development of a study on techniques, processes and tools involved in the preparation of ornament patterns on the curved surfaces of vegetable gourds, called cuias, by a group of craftswomen who belong to a riverbank community dweller of the north region of Brazil. The mathematical aspects involved in the techniques of ornamentation of the gourds, as well as the craftswomen learning processes, constituted our interest of research.

The continuity of this work resides in the school context of the Aritapera Region, seeking to observe how the different manifestations of knowledge are found within the school curriculum, and how scholarly knowledge is articulated with local knowledge. So far, Mafra is leading a collaborative project, together with local teachers and a group of craftswomen, looking into the possibility of linking handicraft work and the current local curriculum, at different levels of education, depending on content or area of knowledge. Our first conclusions underscore the need for training teachers, in order to prompt them to use the traditional knowledge, beliefs, and worldviews of their local community (VANDENDRIESSCHE et al., 2017).

The collaborative educational project is being implemented in communities of the Aritapera Region, city of Santarém, north of Brazil. This region has as geographical characteristics: humid tropical forest (typical of Amazon forest), low floodplain area (in winter, permanently flooded), natural fields, cerrado, rivers, large lakes and streams.

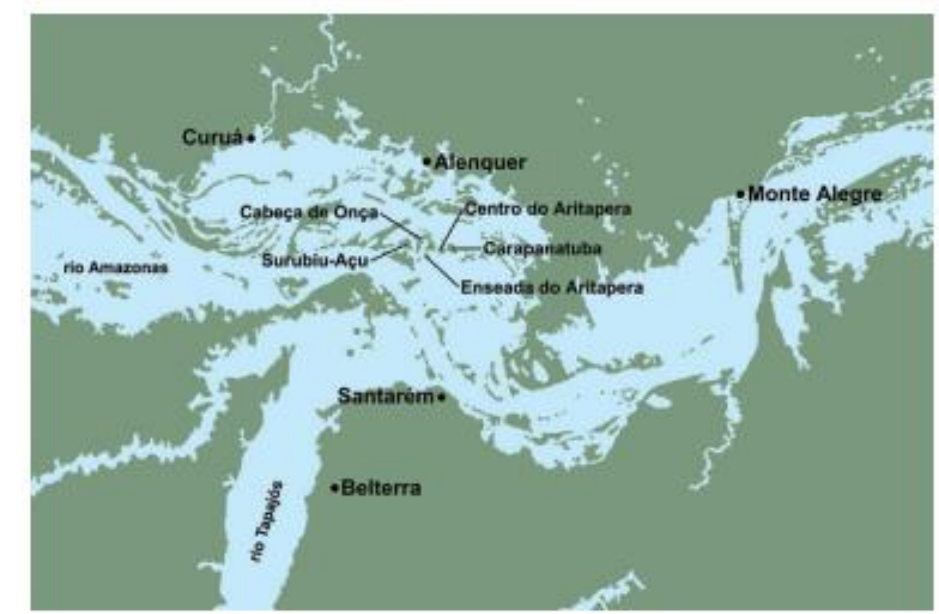

Figure 1: Map of Aritapera Region, Santarém, Brazil (CARVALHO, 2011, p. 28)

The project involves a collaboration with researchers, artisans and elementary school teachers that work in the local school. The artisans are organized in an Association, the Santarém 
Riverbank Craftswomen Association (ASARISAN), founded in 2003. The gourds crafting production is an antique traditional cultural practice developed by the women in this area, especially during the flooding season Maduro (2013). There is a variation on the devices and techniques applied on the carvings. Every craftswoman seems to dispose of a wide range of creative possibilities, regarding both the size and decoration of the gourds, depending on their different uses. There are basically two kinds of ornament patterns: the floral or the tapajonic (cf. Figure 2). (FANTINATO \& MAFRA, 2017)

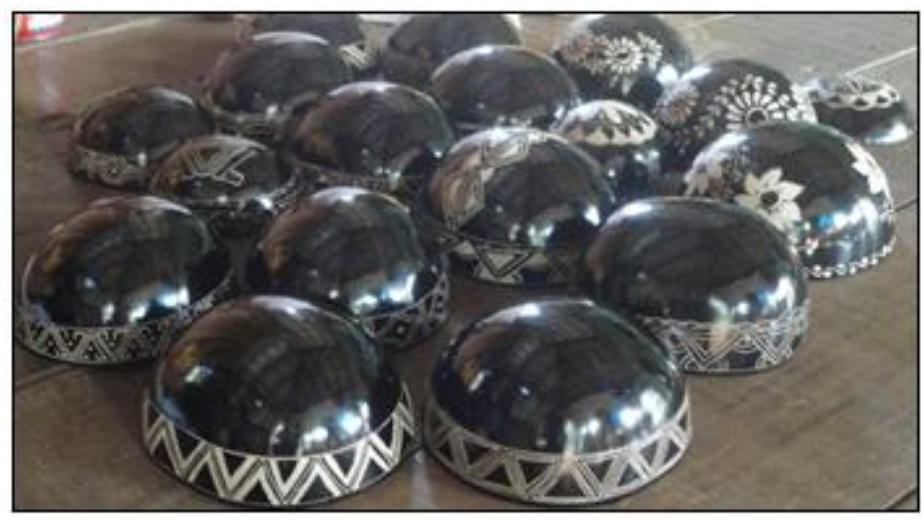

Figure 2: Handcrafted gourds with tapajonic (in the front) and floral (at the back) patterns (Photo by the authors, with ASARISAN`s authorization)

The artisans reside in diverse locations scattered throughout the Aritapera Region. Access to their homes is by the rivers and streams of the region, through small and medium boats, canoes, hulls or bajaras ${ }^{1}$. The manufacture of handcrafted bowls is made in small covered spaces, very close to their homes.

The school in which the activities are being developed is the São Sebastião Municipal Elementary School. It is located in the community of Carapanatuba, Aritapera Region. School operates in the morning and afternoon shifts, with elementary classes (grades 1 to 9). Three teachers have participated of the first stage of the project, analyzed in this paper. One of them is from Aritapera region, but the other two live in the urban area. They all have attended the Pedagogy course at the Federal University of Pará.

\section{The gradual implementation of the collaborative project}

In this article, we present the work that was developed in the Aritapera community, together with the teachers of the Region, during the first half of 2019. This work involves math curriculum content and traditional knowledge, designing activities aimed at teaching children from 0 to 9 years.

\footnotetext{
${ }^{1}$ Small boat used in daily transport of people and utensils on Amazonian rivers.
} 
Moreover, the elaboration of mathematical situations related to geometry, fractions, measurements and basic arithmetic are important elements for the future elaboration of regionalized textbooks, in which the strength of traditions, such as the Aritapera community, is present.

The pedagogical work based on these cultural elements can be an instrument against the possible disappearance of both the traditional activities of Aritapera (the local context) and the different cultures existing in the different regions of our planet (the global context). These elements can be worked through pedagogical support materials, to be gradually assimilated in school contexts. For this to happen, it is essential that teachers acquire necessary values and skills, so that they have confidence when deciding to practice unprecedented procedures in their teaching activities.

The work developed with the teachers allowed a discussion about the cognitive aspects present in the processes of elaboration of proposed activities, in learning environments. Such implementation requires, from the teacher, an interaction with the pedagogical components that integrate the activities. It also requires a reconfiguration of teachers' conceptions and beliefs. This process implies a somewhat radical revision of many conceptions, beliefs, values and attitudes related to mathematics teaching, seeking the gradual incorporation of contextual activities into teaching and learning practices.

The work developed with the teachers had the initial discussion of a text from one of our theoretical references, Domite (2000), which addresses the issue of teacher education from the perspective of ethnomathematics. As quoted by this author (DOMITE, 2000, p. 44):

[...] we are seeking to help the teacher to establish cultural models of belief, thought and behavior, in order to reflect not only the potential of the pedagogical work that takes into account the "knowledge" of the students as well as that of a more meaningful learning by the school that gives more power and mastery over the learning itself.

Under these conditions, a possible interaction between teacher/student is ensured, from a construction/re-elaboration of knowledge, thus meeting a certain request for intellectual autonomy by the learner. This autonomy would be directly related to the teacher's ability for guidance/clarification and security in creating spaces for mathematical knowledge, together with the students, by using practices and techniques developed in their surroundings (in our case, the handmade gourds).

The above elements also find resonance in D'Ambrosio (2003, p. 79), when he mentions what the teacher of the future would be like in his teaching action: 
[...] will be valued for his action as a cultural animator and critical commentator, and for his ability to highlight the transcultural and transdisciplinary aspects of knowledge. Its activities will have as its starting point the experience in different environments of the classroom, associated with leisure and doing. The quality of future education will depend on the good use of extra-walled spaces, [...] and out-of-school activities such as community research, ecological and theme parks, and museums.

Attention is drawn to the non-disciplinary aspect in the characteristics listed by the author, indicating another means of dealing with the appropriation of mathematical knowledge by students. These meanings integrate into a transversal perspective in terms of content, concepts and procedures, according to the natural environment and the internal structure of representations produced by people, located in time and space. A pedagogical proposal that considers the above characteristics should include not only knowledge and procedures conceived as transversal themes, but also any event that deserves proper attention and a possible solution.

Thus, one of the fundamental roles of pedagogical approaches based on ethnomathematics studies is to show that there are alternative ways to acquire knowledge, based on the voice of people, children or students. Knowledge, according to Abreu Jr. (1996, p. 175), "is mainly in experiences, in history, in social life that takes place outside the classroom walls. The school is the meeting place, discussion and humanization of relations around the construction of knowledge". These are important characteristics, established as references in the construction of an ethnomathematical pedagogy, from an essentially transdisciplinary perspective.

To achieve this, a long process of awareness of our future teachers is necessary, in line with studies and research in ethnomathematics, from the formation of teams and transdisciplinary groups, aiming at acting in the classroom.

This is therefore a challenging issue for teacher education courses. It requires a thorough discussion of knowledge and our inability to deal with dynamic and natural situations, thus overcoming a disciplinary approach. These are challenges that have been out for some time but still deserve further discussion.

The work developed by the Aritapera artisans in the production of the gourds and their iconographic representations represents a transdisciplinary movement, in terms of knowledge. Such movement allows the identification of points of intersection between methods and techniques used by a group of artisans in a community of practice, producing a local science, with perspectives of its use for educational purposes.

The group of artisan women transmits to their successors, through their practices and 
techniques, specific symbols, forms, gestures and vocabulary, which design conscious and unconscious strategies of thought, enabling the artistic production of artifacts and their records. From the educational point of view, such strategies can be transposed to the school context, so that such structures conceived mentally by the artisans can be projected from elaborate and organized activities aiming at the cognitive development of the students, through didactic situations based on traditional knowledge (in this case, the incisions made in gourds).

This makes us reflect a little on the need to provide characteristic elements of this nonfragmentary nature for learning environments in order to stimulate dynamics among the components of a classroom. One of these implications was a focus of the study based on the sociocultural aspects that constitute the basis of group identity, as elements of motivation and implementation in the local school context. Despite the permanent difficulties in the region, such as long geographical distances, high turnover or lack of teachers in the region's schools, infrastructure difficulties, among others, these elements have certainly become the main path for the initial draft of a pedagogical proposal, based on local traditional knowledge.

\section{Elements of cultural traditions as a source of content for the school curriculum}

We base the initial formulation, planning and structural configuration of the conception of our proposal, starting from specific problems of populations, traditions and cultural values perceived in diverse social groups and environments. In our study we focused on the community of Aritapera and Vanuatu (VANDENDRIESSCHE et al., 2017; FRANÇOIS et al., 2018), specifically the group of female artisans residing in the community Aritapera and in Vanuatu ${ }^{2}$ With this We had in view the expansion of this knowledge and cultural and secular values as teaching practices in the school of the region, as an instrument of understanding the real and of problem solving practice, based on their varied needs.

Based on these assumptions, we carried out a series of activities involving the formulation, elaboration and initial operationalization (in progress) of activity modules in 3rd and 4th grade classes, during 2019, aiming at the effective application in these classes. In the next months.

The methodological referral suggested and implemented for this stage of the work consisted mainly of periodic planning meetings and theoretical discussion about the proposal, with a group of three teachers from the region, hereafter called Maria Laura, Elza and Beatriz. The initial

\footnotetext{
${ }^{2}$ In this article, we will focus on the actions developed in the Aritapera Community, with the artisans. In a close work we will have the opportunity to know the initial actions of the pedagogical practices developed in Vanuatu.
} 
discussions were based on the understanding of the techniques and strategies used by the artisans in their social practices and how these knowledges can be developed and abstracted in learning environments by teachers, through the formulation, elaboration and operating modules of activities based on the community context in classes of elementary school.

These activities are intended to be developed in both school and non-school spaces, involving the construction of representations and spellings, thus reflecting the knowledge historically constructed in the region.

Thus, the planned activities were organized, projecting perspectives of school contents according to the existing cultural records in the community, related to handmade gourds - for a didactic matter, in three modules, whose menus are presented below:

I. Specific measurements and standards: notions of measurements, materials and measurement standards, the body as a reference for determining measurements. Proportionality. Local Measurement Standards. (5 teaching activities).

II. flat records and incisions: flat shapes and representations, in different configurations. Handmade construction of drawings on gourds as a teaching activity. Reproduction and variation of shape and dimension. Trial and error. Naming and creating alternative formats. (8 teaching activities).

III. Ornamental distribution strategies. Marking and location referential strategies. Repetition Patterns. Geometric transformations. Isometry, rotation and symmetry in handcrafted bowls. (7 teaching activities).

With this initial planning experience, we verified some points of view taken from our inferences, pertinent to aspects and manifestations of the teachers participating in our work. The incorporation and acceptance of cultural aspects in teaching practice certainly tends to cause reflection or even a revision in the practice of many teachers. It is interesting that the teacher considers different forms of mathematical strategies and procedures valid from records of people belonging to the same population ${ }^{3}$, and for the researcher to find similar techniques or procedures in different cultures ${ }^{4}$.

These elements point to the emergence of new teaching and learning assumptions to be

\footnotetext{
3 This is not an easy task, as it is necessary for the teacher to have a logical understanding of the student's thought process, which is often only possible via oral interlocution aided by student information through the identification and location of students. logical schemes, involved in their records.

${ }_{4}^{4}$ Another challenging task given that it would take considerable research and availability time to be in other distinct contexts and other factors.
} 
built, as proposals are implemented from the perspective of transversality. In our research, we seek to focus on possibilities of work not only related to the formal mathematical ideas and strategies of approximation of results proposed by the students, but also seek to advance in terms of links and connections with other disciplines, based on the knowledge produced in own community.

We will present below some of the proposed activities in our research, which their organization and structure are related to the work of Mafra (2006). They are organized the s plan s teaching of 5 (five) activities related to the Aritapera gourds. These activities were carried out between May and July 2019, within the geographical context of the Aritapera community.

\section{Activity 1: Initial Activity: A class with Aritapera artisans}

Theme / Title: Informal Knowledge in the Classroom

Objectives of the class:

- Provide a space to know and learn from the knowledge of the artisans of Aritapera, in the process of making handmade gourds.

- Assist and listen to the artisans, in relation to their activities of elaboration of handmade gourds.

- Dialogue with the artisans regarding culturally and socially referenced knowledge.

Class Development Procedures / Steps: Successful class with the participation of the artisans.

Methods and techniques employed: according to the techniques and strategies used by the artisans during the process of elaboration of the iconographic records (photos and records below) in the form of tapajonic and floral arrangements, in handmade gourds.

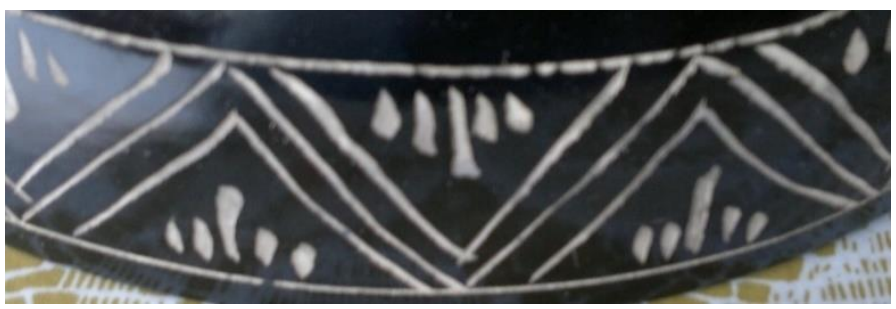

Figure 3: Engraved in gourds, in tapajonic form (Photo by the authors, with ASARISAN's authorization)

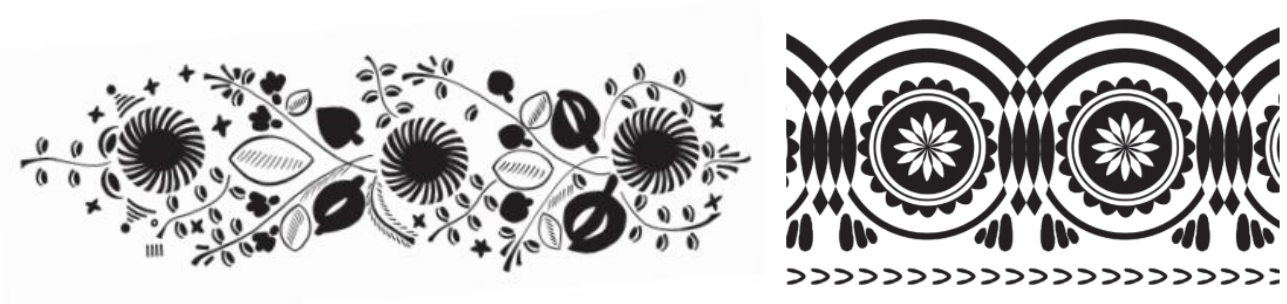

Figure 4: Engraved illustrations in the form of floral arrangement (CARVALHO, 2011, p. 98 and 120) 
Curriculum contents to be worked on: knowledge of Aritapera artisans generated in the context and surrounding community, school location.

Assessment Techniques: observation and attention in the activities to be developed. Preparation of report (written text) by students at the end of class, aiming to describe the events that occurred.

\section{Activity 2: Repetition Patterns}

Theme / Title: Teaching Repeating Patterns and Geometric Settings

Objectives of the class:

- Learn how to develop strategies (draw or record on paper) needed to construct patterns characteristic of Aritapera regional gourds.

- List regional terms and nomenclatures used by artisans, aiming at the identification of communication styles.

- Relate cultural information with curriculum information, related to mathematical ideas

Procedures/Stages of class development: The activities will be developed, from the initial elaboration, of flat representations (examples of records below), similar to those elaborated by the artisans, in the elaboration of the handmade gourds.

Methods and techniques employed: paper, pencil, ruler and other necessary school instruments.

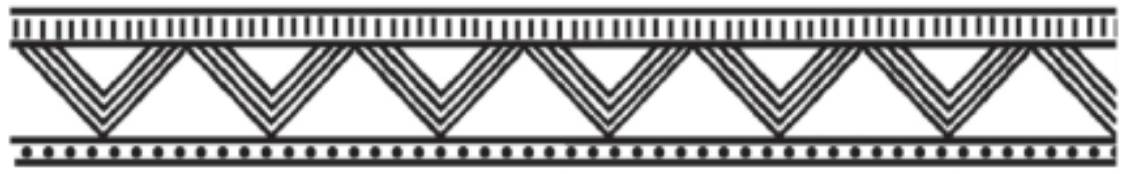

Figure 5: Illustration of a suggestive pattern of repetition (CARVALHO, 2011, p. 184)

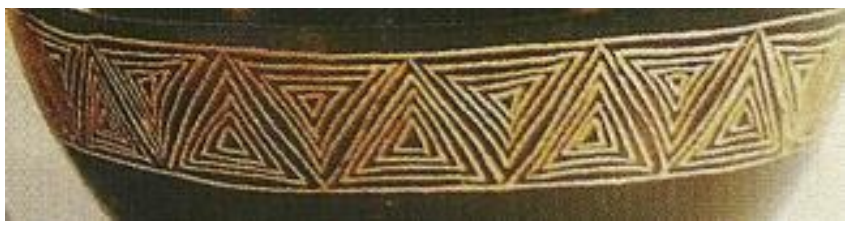

Figure 6: Tapajonic history engraved, in a gourd (CARVALHO, 2003, cover photo)

Curriculum contents to be worked on: spatiality and scale construction, geometric figures, representations of objects and reference points, plane geometric figures. 


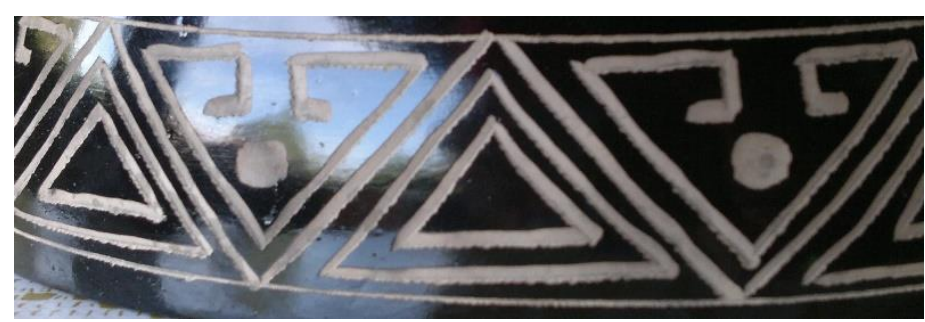

Figure 7: Tapajonic history engraved, in a gourd (Photo by the authors, with ASARISAN`s authorization)

Assessment Techniques: activities produced by the students. Organization of ideas and discussions related to the knowledge learned by the artisans and the knowledge produced, resulting from the teachings of the school curriculum.

\section{Activity 3: Symmetries}

Theme/Title: Learning to Build Knowledge on Geometric Transformations

Objectives of the class:

- Arrange records of illustrations similar to gourd items, shown in the templates below.

- Collectively discuss the strategies and procedures used.

Procedures / Stages of class development: The activities will be developed, from the initial elaboration, of flat representations (examples of records below), similar to those elaborated by the artisans, in the elaboration of the handmade gourds. Work involving the construction of symmetries and similar figures.

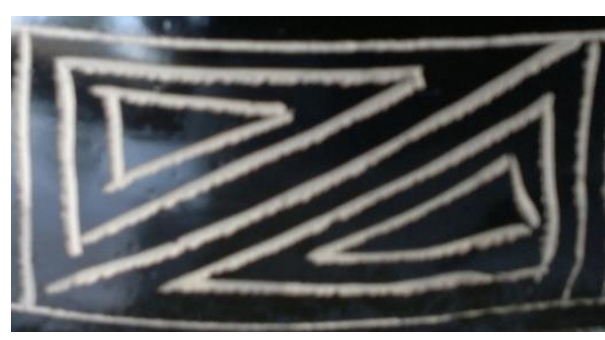

Figure 8: Examples of recurrent gourd patterns (Photo by the authors, with ASARISAN`s authorization)

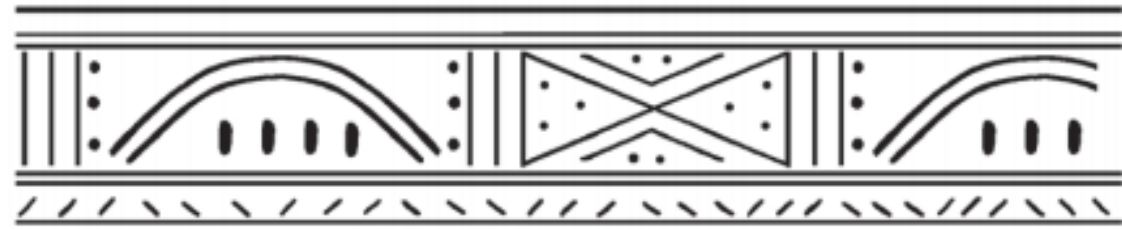

Figure 9: Examples of recurring gourd patterns (CARVALHO, 2003, p. 15)

Methods and techniques employed: paper, pencil, ruler and other necessary instruments. 
Curriculum contents to be worked on: proportion, equal partitioning, initial notions of fractions, geometric figures, representations of objects and landmarks, flat geometric figures, measures of length: registration, measuring instruments, estimates and comparisons, symmetries of reflection. Situations local problems.

Assessment Techniques: ability to order ideas and strategies, aiming at the elaboration of representations and iconographic records.

\section{Activity 4: Elaboration of gourd incisions: own strategies ${ }^{5}$}

Theme / Title: Construction of records and engravings in gourds

Objectives of the class:

- Provide a moment for the student to elaborate gourd items as known in previous activities.

\section{Class Development Procedures / Steps:}

- Free activities will be developed, with the proper supervision of the participants (teachers and parents), in order to work on the development of recording strategies, in handmade gourds, such as the records presented below.

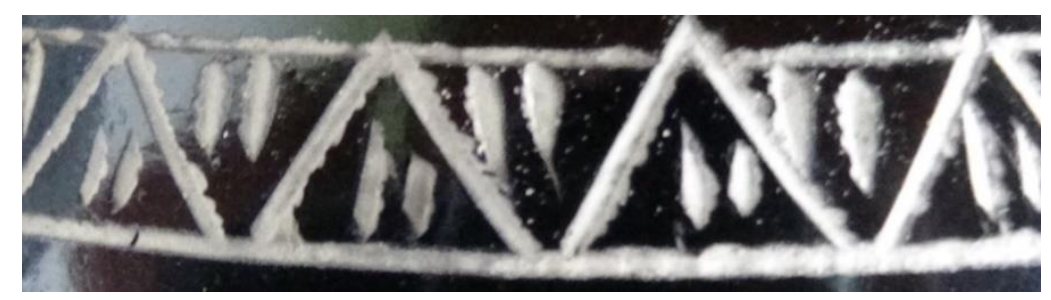

Figure 10: Iconic history engraved in gourd (Photo by the authors, with ASARISAN`s authorization)

Methods and techniques employed: gourds and instruments necessary for the elaboration of handcrafted prints, in this activity we will have the participation of the students' parents, in order to supervise them in the elaboration process. (The age range of students requires this because they use sharp instruments).

\footnotetext{
${ }^{5}$ This activity was inspired by the workshop developed by the Fluminense Federal University's Ethnomathematics Group - GETUFF, which took place during the 5th National Congress of Ethnomathematics, in 2016, at the Federal University of Goias - UFG/Brazil.
} 


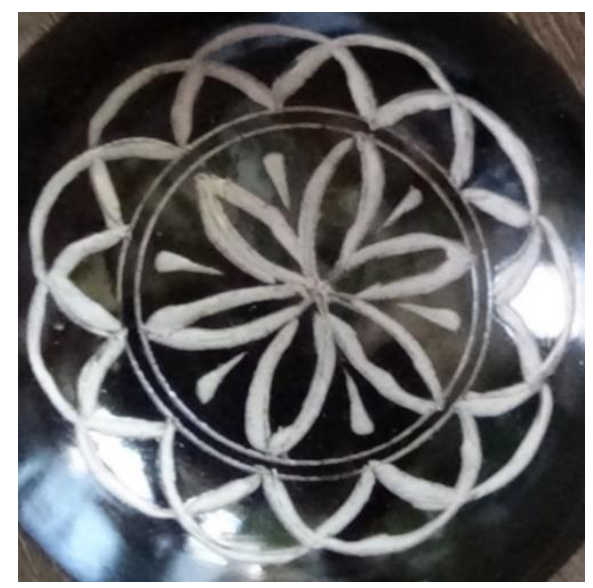

Figure 11: Iconic registration in gourd (Photo by the authors, with ASARISAN's authorization)

Curriculum contents to be worked on: proportion, equal partitioning, initial notions of fractions, geometric figures, representations of objects and landmarks, flat geometric figures, measures of length: record, measuring instruments, estimates and comparisons.

Assessment Techniques: ability to order ideas and strategies, aiming at the elaboration of representations and iconographic records.

One question: did you perform your activities on a plan (sheet of paper, for example). It is now developing similar activities on a curved surface (gourds). What differs from each other? Difficulties? Which are?

\section{Activity 5: Expansive Activities: Other Disciplinary Fields}

Theme/Title: Interdisciplinary Activities

Objectives of the class: to establish relationships between the disseminated knowledge, due to the manufacture of handmade gourds, based on mathematical ideas and possible relations with other areas of knowledge.

Class Development Procedures / Steps:

- Based on the map below, make a record or illustrative drawing of where you live and also where the artisans do their gourd making work. 


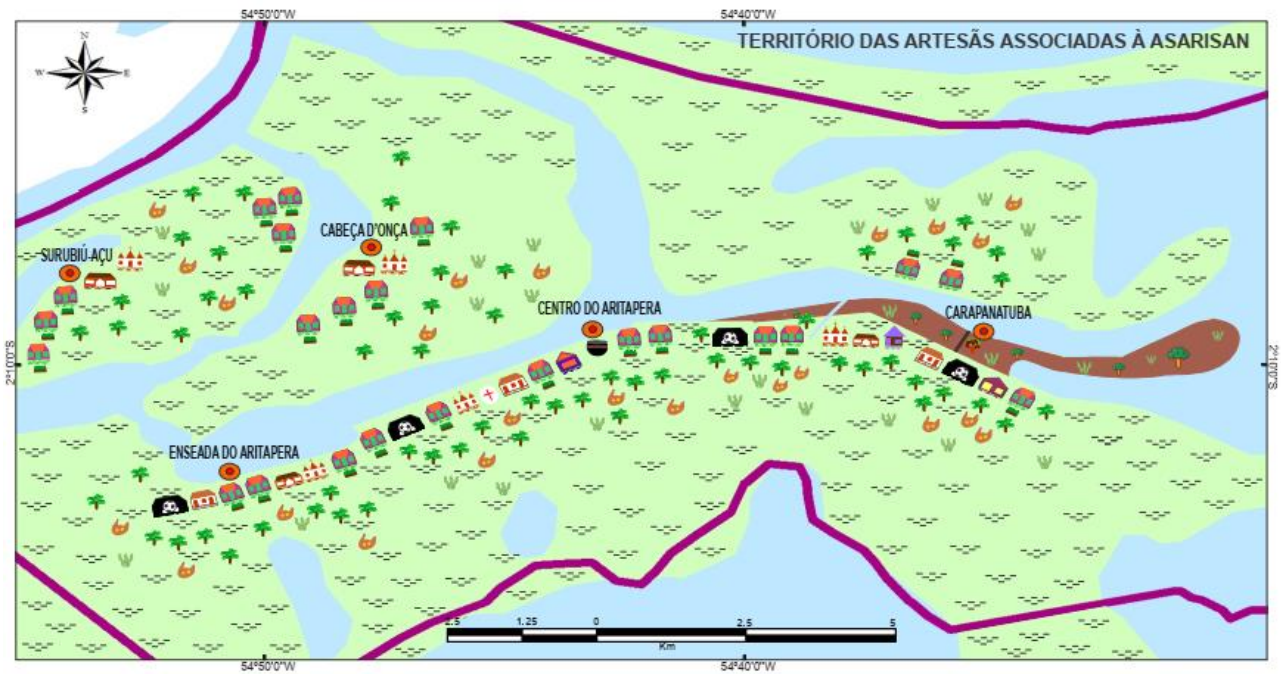

Figure 12: Illustrative map - ASARISAN (ALMEIDA, 2013, p. 8)

Develop an essay to tell the stories you know about Aritapera artisans.

Methods and techniques employed: paper, pencil, ruler and other necessary school instruments. In this activity we will have the participation of the artisans and the "elders" in a "telling" of stories and stories.

Curriculum contents to be worked on: Artistic elements (arts education and arts); elaboration of textual production and writing (Portuguese language); working religion, the imaginary and the mythical in the child (history and religious studies); spatiality, scale construction, proportion and notions of location (mathematics and geography)

Assessment Techniques: capacity for abstraction and dialogue of local knowledge, with different areas of formal knowledge.

\section{Commentaries}

The examples of activities presented above are based on knowledge of the region, more specifically on the production of artisan gourds and how they can be incorporated into school activities. Thus, the development of the activities seeks to establish a communication relationship between the knowledge of the historically constructed artisans and the curricular contents contemplated for the 3rd and 4th grades, according to the guidelines issued by the State Department of Education and incorporation from the National Curricular Base Common (BNCC). What was proposed, in fact, is nothing more than an attempt to articulate this traditional knowledge existing in the community and its potential as a generating element of pedagogical discussions between students and teachers. 
Just having an initial planning discussion with the teachers - about this cultural knowledge produced and existing in the community, and how it can be operationalized into the classroom has in itself made a change possible. Expectations and behavior of teachers and students.

Thus, the activities produced were organized in such a way that they could promote a clear relationship with the real context in which those involved were inserted, seeking dialogue or articulation between fields of knowledge construction considered distinct (formal context and informal context). Thus, the knowledge produced and culturally identified in the group of artisans of the Aritapera community became a reference for the teaching and learning of school concepts.

In our ethnographic observations Fantinato \& Mafra (2017); Mafra \& Fantinato (2016) we identified no less important considerations regarding the manipulative aspects of the act of elaborating the records / items. Registered procedures not so far from those used in fitness calculations, such as counting and, proportionality. Some artisans make calculations by estimation, that is, by head, which presupposes the idea that the representations and spellings developed over the years are already mentalized. As this is or is not related to the ability to concentrate and support validation of actions developed, it is expected to identify, in the development of educational practices, with students.

Obviously, the empirical knowledge built over the years of working with the gourds provides us with different explanations for the observed event, in terms of elaborate spatial relations and idealized step-by-step constructions (algorithms?). According to the artisans, testimonials - such as "to draw a picture, come from within us, 'doing it here,' seeing that it will work [...]", "look at the model and reproduce it "," Goes as big as we want [...] we really take it out of our head "and or" my brand is in the eyes" shows how relevant the diversity of techniques and strategies is, thus showing a collective work real, characteristic of a community of practice.

And in school? Will this be possible? As (and if) this will be possible, we will know when we carry out the experimental practice, planned for the coming months.

\section{Notes for reflection: need for change or coexistence with diversity?}

The work developed in the Aritapera community allows the discussion of aspects related to the sociocultural practices evidenced, when the respective ethnographic researches and their subsequent transposition to the classroom, as a way to develop a cultural school curriculum. In addition, thinking about a proposal to teach curricular academic mathematics, based on existing mathematical principles and ideas in these practices, can provide a discussion by the teacher 
regarding strategies and techniques, similar to those of artisans. On the strategies and techniques abstracted in a problem situation, as suggested in previous activities.

Can such a dialogue (or should) exist in learning environments? The gradual insertion of propositions and discussions consistent with the perspective of the problems and needs of our society becomes relevant not only in mathematical learning environments, but also in interdisciplinary integration. We know the strength and importance of mathematics for the reading and critical interpretation of the world in which we operate. We also know the necessity and importance of mastering this mathematics by our students, so that they can overcome the challenges that are presented to them day by day. Beyond merely mathematical knowledge, a satisfactory understanding of the world tends to be relevant as the meeting of cultures becomes inevitable and permanent, without overlapping knowledge or claims of the above superiorities.

When speaking of a satisfactory understanding of our world, we refer to possibilities of understanding differences and respect for them, which are very little disseminated in our schools. This implies admitting forms of knowledge considered different and identical at the same time. Different, because there are records of symbolic representation and thought structures configured based on myths, beliefs and legitimized languages, but similar, regarding the path of solution, pursued goals and solidary communication. For Santos, Meneses \& Nunes (2005, p. 54-55),

over the centuries, the constellations of knowledge have developed forms of articulation between themselves and today, more than ever, it is important to build a truly dialogic mode of permanent engagement, linking the structures of modern / scientific / western knowledge to native / local / cultural formations. traditional knowledge [...] In conclusion, it can be said that the epistemic diversity of the world is potentially infinite, since all knowledge is contextual. There is neither pure knowledge nor complete knowledge; there are constellations of knowledge.

According to Santos, the possible communications between these constellations of knowledge are provided by the proposition and implementation of a dialogic and gradual process. Such an effort can be determined by grasping the microstructures supporting these constellations as well as by identifying the communication flows that may exist between them. The educational activities proposed and to be carried out with the students of the initial grades, would allow to project possibilities of these communication flows, capable of providing elements of abstractions and representations coming from the conceptions and cultural structures existing in each context of the ethnographic research performed.

In this sense, the initial planning, developed jointly with the teachers in the Aritapera 
community, points to the existence of multiple possible, legitimate ways of knowing and knowing, provided that these paths are legitimized, validated, practiced and disseminated within the school. Beyond the simple valorization of local knowledge, considered by many as peripheral. Moreover, the ongoing investigation, provided by reading the cognitive construction processes involved in this knowledge, allow us to bring some reflections to our different concerns, especially those that provide indicators of coexistence and cultural support. In the words of Silva (2004, p. 197), it is not just a simple valorization, but.

To view the cultures of the dominated groups in an anthropological way, as a manifestation and expression of ways of organizing social life that exist alongside equally valid ones. From this perspective, it is not a question of 'starting from the dominated culture', but rather questioning it, questioning it, historicizing it, just as it should be done with the dominant culture. It is not a question of overcoming it, to enter another, but of asking questions that reveal its history, the history that produced the present social identities and placed them in subordinate relationship in the existing social configuration.

Effective action in the classroom, are expected $s$ to take place in October and November 2019, according to the activities developed in Aritapera Region, and according to the curricular perspectives presented above.

Importantly, the opportunity to build an initial scheme for the development of discussions in traditional school environments, through situations, issues and problems immersed in the context of the artisans, presents a different and skeptical reflection regarding the teachers involved. (Elza's question: How will I use the knowledge generated from the production of handmade gourds to teach mathematics?).

The community as a whole looks forward to the implementation of the proposed actions in the classroom. In this sense, a sharp discussion about the behavior of this initial model may allow evidence of successful experiences, typical of local contexts. This, no doubt, may indicate a discussion more related to the philosophy and sociology of knowledge, with a view to clarifying and raising awareness of the actors involved in the teaching and learning cycle.

Thus, future research in different contexts, design planning educational projects based on traditional and cultural aspects as proposed to the community of Aritapera.

Thus, in this investigative direction, it is possible to find divergent, convergent or adjacent results with which we have compacted and believed. These epistemologies certainly converge to form a vast field of research under development, especially in studies and discoveries that may contribute to the provision of new data, new information and new ethnomathematic knowledge. 


\section{References}

ABREU JR., Laerthe. Conhecimento transdisciplinar. o cenário epistemológico da complexidade. Piracicaba: Editora Unimep, 1996.

ALMEIDA, Alfredo Wagner Berno de. (Coord.) Nova Cartografia Social da Amazônia: arte na cuia: experiência tradicional de saber fazer. Manaus: UEA Edições, 2013.

BOGDAN, Robert C.; BIKLEN, Sari Knopp. Investigação qualitativa em Educação: uma introdução à teoria e aos métodos. Tradução de Maria João Alvarez, Sara Bahia dos Santos e Telmo Mourinho Baptista. Porto: Porto Editora, 1994.

CARVALHO, Luciana Gonçalves de. (Org.) O artesanato de cuias em perspectiva - Santarém. Rio de Janeiro: IPHAN; CNFCP, 2011.

CARVALHO, Luciana Gonçalves. Cuias de Santarém. Rio de Janeiro: FUNARTE; CNFCP, 2003.

D'AMBROSIO, Ubiratan. Espaços transculturais e transdisciplinares na educação. In: MATOS, Cauê. (Org.). Ciência e arte: imaginário e descoberta. São Paulo: Terceira Margem, 2003, p. 7579.

D’AMBROSIO, Ubiratan. Transdisciplinaridade. São Paulo: Palas Athenas, 1997.

VARGAS, Sônia de. Estratégias não-escolares de ensino-aprendizagem e formação de professores da EJA. In FANTINATO, Maria Cecília (Org.) Etnomatemática: novos desafios teóricos e pedagógicos. Niterói/RJ: Editora da UFF, 2009, p. 193-201.

DOMITE, Maria do Carmo Santos. Notas sobre a formação de professores e professoras numa perspectiva da etnomatemática. In: CONGRESSO BRASILEIRO DE ETNOMATEMÁTICA, 1, 2000, São Paulo. Anais do CBEm1. São Paulo: FE-USP, 2000, p. 41-48.

FANTINATO, Maria Vecília; MAFRA, José Ricardo. Techniques and learning process of craftswomen in Brazil. In: ROSA Milton; SHIRLEY Lawrence; GAVARRETE Maria, ALANGUI, Wilfredo (Ed.). Ethnomathematics and its Diverse Approaches for Mathematics Education. Switzerland, Hamburg/Germany: Springer International Publishing, 2017, p. 69-93.

FRANÇOIS, Karen; MAFRA, José Ricardo; FANTINATO Maria Cecília; VANDENDRIESSCHE, Eric. Local Mathematics Education: the implementation of local Mathematical practices into the Mathematics Curriculum. Philosophy of Mathematics Education Journal, n. 33, p. 1-18, jan. 2018.

GEERTZ, Clifford. A Interpretação das culturas. 1. ed. 13ª reimpr. Rio de Janeiro: LTC, 2008.

GREENFIELD, Patricia; LAVE, Jean. Aspects cognitifs de l'éducation non scolaire. Recherche, Pédagogie et Culture, n. 44, p. 16-35, 1979.

MADURO, Rubia. A cuia nossa de cada dia. In: SANTOS, Antônio; CARVALHO, Luciana (Org.) Terra, água, mulheres e cuias: Aritapera, Santarém, Pará, Amazônia. Santarém: UFOPA, 2013, p. 32-38.

MAFRA José Ricardo. Espaços transversais em Educação Matemática: uma contribuição para a formação de professores na perspectiva etnomatemática. 2006. 210f. Tese (Doutorado em Educação) - Centro de Ciências Sociais Aplicadas. Universidade Federal do Rio Grande do Norte. Natal. 
MAFRA José Ricardo; FANTINATO, Maria Cecilia. Artesãs de Aritapera/PA: técnicas e processos em uma perspetiva Etnomatemática. Revista Latinoamericana de Etnomatemática, San Juan de Pasto, v. 9, n. 2, p. 180-201, 2016.

PAIS, Alexandre. Criticisms and contradictions of Ethnomathematics. Educational Studies in Mathematics, v. 76, n. 2, p. 209-230, mar. 2011.

SANTOS, Boaventura de Souza; MENESES, Maria Paula; NUNES, João Arriscalo. Para ampliar o cânone da ciência: a diversidade epistemológica do mundo. In: SANTOS, Boaventura de Souza. (Org.). Semear outras soluções: os caminhos da biodiversidade e dos conhecimentos rivais. Rio de Janeiro: Civilização Brasileira, 2005, p. 21-25.

SILVA, Tomaz Tadeu da. Os novos mapas culturais e o lugar do currículo numa paisagem pósmoderna. In: MOREIRA, Antônio Flávio; SILVA Tomaz Tadeu da. (Org.). Territórios contestados: o currículo e os novos mapas políticos e culturais. 6. ed. Petrópolis: Vozes, 2004, p. 184-202.

VANDENDRIESSCHE, Eric; MAFRA, José Ricardo; FANTINATO, Maria Cecilia; FRANÇOIS, Karen. How Local are Local People? Beyond Exoticism. 9th INTERNATIONAL MATHEMATICS EDUCATION AND SOCIETY CONFERENCE. Proceedings MES9, v. 2. Volos, Greece: University of Thessaly Press, 2017, p. 956-967.

ŽlŽEK, Slavoj. Multiculturalism, or, the cultural logic of multinational capitalism. New Left Review I/225, 1997. 